\title{
A patient's diary: episode 19 - A shocking experience
}

The palpitations started this morning while I was mowing the lawn. It's quite a heavy machine but you do get proper stripes which I don't believe is possible with the electric kind, quite apart from the possible dangers of being run down or electrocuted.

Anyway, I had just completed the bumpy section in the middle of the back lawn when I felt an irregular knocking in my chest, a bit like a car backfiring, and my heart was pounding away at a terrific rate. I realised at once that the knocking was coming from my heart which must have somehow slipped out of gear with the force of my exertions. I really wasn't expecting anything to go wrong with my heart because I have always been so careful with it, eating only Tulip Margarine (high in Benecol and Polyunsaturates) with my toast and doing my exercises religiously every morning. And more recently, persuading Nurse Katie to let me go on Superstatin because although my risk is still only $5 \%$ of a heart attack in 10 years, in my view it's foolish to take any risk at all if you can avoid it. Perhaps I should have had one of those implantable defibrillators fitted to prevent this sort of thing from happening. Amazing how one never thinks of these simple precautions until it is too late.

I sat down on the garden seat, called weakly for Hilda and tried to find my pulse. I called again but there was no response. Then I remembered that Hilda had gone to do the Saturday shopping while I got on with the garden. I was alone except for the garden gnome who had a look of concern on his wise old face (or so it seemed to me) but being made of Plaster of Paris he was unable to render any assistance. I felt for my mobile phone but I had left it in the house, in my top jacket pocket. Somehow I managed to stagger into the house, my heart still thumping away, and phoned for a doctor. It was just before 11.30 so Saturday surgery would not quite have ended. But who was on duty? As the dialling tone purred away endlessly I wondered who it would be and whether they would reach me in time. Suppose they had closed early and switched over to the OOHDOC service for the rest of the weekend? It didn't bear thinking about. Then there was a click and a gruff voice said: 'Yes?' I immediately recognised $\mathrm{Dr}$ Arthur Grimes, the oldest and least compassionate member of the partnership whom I generally avoid, if possible.

'It's me, Dr Grimes,' I faltered, 'Norman Gland of 22 Chestnut Avenue. Can you come at once. It's my heart, it's beating.' Well, I knew as soon as I said it that was the wrong word. I meant to say knocking. There was a choking sound from the other end and Dr Grimes said, 'Of course it's beating! What do you expect it to do? Now look here do you realise that not only is it Saturday but surgery has finished. Kindly phone again on Monday.' 'No, please, $\mathrm{Dr}$ Grimes,' I gasped, 'you don't understand. It's beating too quickly and it keeps backfiring! And it's all jumbled.' Suddenly old Arthur became interested. 'Palpitations, eh? And irregularly irregular by the sound of it. That's different. Why didn't you say so? Now listen to me. Stay exactly where you are and I'll be round in 10 minutes with my ECG machine.' Then I remembered that old Arthur is very keen on hearts. They say he could have been a heart specialist when he was young, but his father wanted him to help with the practice, so he had to give up his higher ambitions and that's why he's so bitter and world-weary. Well partly, anyway.

I lay on the sofa, palpitating away and wondering whether I would last till he arrived. Could my heart stand up to the strain of all this knocking without bursting? Would Dr Grimes know what to do anyway? Things must have changed a good deal since his hospital days. Maybe I should have called an ambulance. Then I saw his car drawing up to our gate and I managed to crawl to the front door to let him in. He had his medical bag in one hand and a large battered looking suitcase thing, containing the ECG machine, in the other. He put both bags down and felt my pulse, timing it against the gold watch he keeps in his waistcoat pocket. I watched his face anxiously, trying to read from his expression whether it was anything Serious.

'Just as I thought,' he said at last, 'rapid atrial fibrillation. But we shall need an ECG to confirm it. Let's get your things off and hook you up to my machine.' I wondered if I shouldn't really be in hospital, but I didn't like to say anything because he looked so pleased with himself as he fiddled with the wires and little metal plates. He soon had me stripped to the waist, minus my shoes and socks and lying on the settee. Then he fastened the plates to my wrists and ankles with little rubbery straps, some of which were a bit ancient and crumbly. Then he tried to attach a little rubber bulb to my chest but it wouldn't stick in spite of repeated applications of jelly. Dr Grimes was undismayed and he hummed a little tune as he worked. Finally with a cry of triumph he managed to stick the electrode on my chest and I lay back patiently to await the verdict. I couldn't hear anything or see any paper coming out and I wasn't sure if the machine was actually working. It soon became clear that it wasn't because Dr Grimes' happy smile turned to a frown of displeasure as he twiddled the dials to and fro.

'We don't seem to be getting any current here,' he complained. 'Are you sure your fuses are all right?' He had plugged the ECG machine into our standard lamp which is a bit temperamental at the best of times. I would have warned him only I thought his machine would run on batteries like the hospital ones do. I saw that I would have to help him because I am the only person who can deal with that standard lamp. 'Better let me have a look,' I said, 'and undoing a few of my straps I got my head under the lampshade and tried to see if his plug was in securely. I don't think it can have been because, when I touched it, there was a tremendous flash and I felt as 


\section{Mum and me}

if something had kicked me across the room. I collapsed on the floor with the standard lamp on top of me. Dr Grimes looked horrified: 'Are you all right, Gland?' he said hoarsely. Then he felt my pulse again and an expression of wonder came over his face.

'Sinus rhythm,' he breathed. 'You've gone back into sinus rhythm! It must have been the effect of the shock!' And sure enough, the knocking had gone. I felt awful and near to death, but no knocking ... Dr Grimes then explained to me that I had inadvertently done with alternating current what the hospital might have had to do with direct current.

At this point, Hilda returned with her shopping and made some tea which made both of us feel better ( $\mathrm{Dr}$ Grimes had been looking rather pale). To my surprise, Hilda was not overly sympathetic. 'I've been telling him for months to get that lamp fixed, Dr Grimes,' she said, 'but it's in one ear and out the other.' 'God works in mysterious ways, Mrs Gland,' said Dr Grimes solemnly, 'his wonders to perform. Might I trouble you for another cup of your excellent tea, two spoonfuls of sugar please, thank you so much ...'

We are grateful to John Salinsky for these extracts from Norman Gland's diary.

DOI: 10.3399/bjgp08X319576
After the recent documentary on BBC1, 'Mum and me', about Ethel, an elderly woman with Alzheimer's, and her family, I felt very pleased and privileged to be able to ring and speak to my own aged mum. What had she thought about the programme? 'I really admire her daughter for making such a truthful film. And it's scary'.

It is, of course, reasonable to be scared of Alzheimer's, both on an individual and a societal level. What this film did was to confront (some would say, in a confrontational way) the reality of living with the disease and to help families doing so to acknowledge and share the difficulty, the fear, the frustration and the pain.

The filmmaker, Sue Bourne, has made many documentaries about people's lives including one about a group of women supporting each other through breast cancer which was shown just before she herself developed breast cancer. Not being able to share her diagnosis with, and get support from, her mum during the treatment was one of the toughest aspects of the Alzheimer's. Ethel has seen the film but a version with the breast cancer edited out, just in case she did understand.

Sue Bourne began the filming as a personal project to record her mum's progress for herself and her daughter, Holly, and then realised that it would be helpful to share it with others. Both strongwilled women, Ethel and Sue had always had a difficult relationship but when, in the film, despite her incontinence and the weekends away spent cleaning bathroom floors, she hugs her mum and tells her that she loves her, tears arrive for both daughter and viewer.

She has, inevitably, had some criticism about showing the very personal aspects of her mum's condition and care, but much more she has had praise for her honesty. She presents herself as no angel, her frustration at times is evident and, at one point, she comes close to hitting Ethel. But she, Holly and her mum also enjoy being together and they laugh (a lot). It was Holly who first realised that all was not well with her grandma and the strength of their relationship has survived and grown with the disease, partly because of Ethel's positive and uncomplaining personality.

In an interview in the Guardian, ${ }^{1}$ Sue said that what she had realised from watching the footage was that all three of them deal with difficult situations with humour. 'We laugh our way out of emotion'. At one point in the film Ethel points to a man she thinks is her father. Sue tells her that it's actually her husband of 49 years, Jack, who has since died. Ethel laughs: 'That's why he's so bloody familiar'. Another scene is of Sue finding her mother crying and explaining to her gently why she's got reason to be sad, 'Your husband's dead, you've got Alzheimer's, you're in a nursing home ...'. Ethel replies, 'Well, thank you. Now, I'm sad'.

I have discussed the film with several patients caring for relatives with Alzheimer's and they've all been glad that it's been made. The amount of laughter is not typical of these relationships and not everyone can afford to even try to take their relative away for comfortable, if incontinent, weekends, but the emotional suffering, frustration, and occasional anger are common to all. The film provides useful professional learning for medical students, doctors and carers about the reality of living with Alzheimer's. It also encourages us all to enjoy and appreciate mums and dads, grandmas and grandpas before they develop Alzheimer's, which many of them (and us) will do.

\section{Lesley Morrison}

\section{REFERENCE}

1. Robinson J. Falling in love with mum again. http://lifeandhealth.guardian.co.uk/family/story/0,,22 79132,00.html (accessed 17 Jun 2008).

DOI: 10.3399/bjgp08X319585 